\title{
Milk Line as an Indicator of the Harvesting Time of Three Hybrid Seeds of Corn (Zea mays L.)
}

\author{
Célio Trzeciak dos Santos ${ }^{1}$, Valdecir Antoninho Dalpasquale ${ }^{1}$, Carlos Alberto Scapim ${ }^{1}$, \\ Alessandro de Lucca e Braccini ${ }^{1 *}$ and Francisco Carlos Krzyzanowski ${ }^{2}$ \\ ${ }^{1}$ Departamento de Agronomia; Universidade Estadual de Maringá; Av. Colombo, 5790; albraccini@uol.com.br; \\ 87020-900; Maringá - PR - Brazil; ${ }^{2}$ Centro Nacional de Pesquisa de Soja; Empresa Brasileira de Pesquisa \\ Agropecuária - Embrapa Soja; C. P. 231; 86001-970; Londrina - PR - Brazil
}

\begin{abstract}
The experiment was carried out to evaluate the time for harvesting seeds of three hybrids of corn (Zea mays L.) at their best physiological quality and the use of the milk line as an indicator of the physiological seed maturity. Single hybrids CD 1723 and CD 5501 and double hybrid OC 705 seeds were collected for 59 days, every four days, starting 23 days after female flowering. Seed dry weight, moisture content, germination, vigour (cold and accelerated aging tests), black layer formation and seed milk line development were analysed. The harvesting time started 47 days after female flowering with high physiological quality of the seeds identified by a joint analysis of those seven characteristics of them. The milk line at stage 4 proved to be the best indicator of the time to harvest corn seeds for maximum physiological quality, because different stages of milk line development in corn seeds could be easily identified in the filed without any special equipment.
\end{abstract}

Key words: Corn, seeds, harvesting time, milk line

\section{INTRODUCTION}

The desirable characteristics of corn seeds from the field are (1) low moisture content to minimise drying, (2) high accumulated dry weight, and (3) high percentage of vigour, and germination. Black layer formation and milk line development also help to identify the best time for seed harvesting. Corn moisture content has been frequently used in the farm to decide the best harvesting time, although differences have been observed among cultivars around the world. The two major reasons for these differences are: 1) the accepted range for harvest moisture is relatively large (30 - 35\%), and 2 ) the on-farm moisture testers are of low quality.
Vigour by the accelerated aging and the cold test, and also the germination test, as well as the dry weight accumulation are not appropriate for onsite field testing. The black layer, although present in almost all hybrids by the time of physiological maturity, usually forms in only three to five days, a period that is too fast for successful use as a reference for the identification of the best harvesting time for corn seeds. The solidification of the endosperm is slower than black layer formation. All five solidification stages can be the endosperm in parallel with other characteristics mentioned earlier may lead to a more precise and suitable technique for identification of the best time for harvesting corn seeds in the field (Vieira et al., 1995).

*Author for correspondence 
The best harvesting time of corn for consumption is defined differently. In this case, crop production is measured by mass weight in a unit area. Watson, cited by Williams (1965), proposed a growth index as a dry weight per unit area, in a time unit. The most frequently used unit for corn is $\mathrm{kg} / \mathrm{ha} / \mathrm{day}$. Although moisture content has been widely used to determine seed maturity, many researchers concluded that this was not a reliable parameter. It can vary among maturity groups (Hallauer and Russel, 1962; Rench and Shaw, 1971), years, seeding dates (Gunn and Christensen, 1965; Daynard, 1972; Kinittle and Burris, 1976), and also among hybrids (Hillson and Penny, 1965; Carter and Poneleit, 1973).

Among early-maturing hybrids with the same seed moisture at the time of harvesting those flowering later showed higher yield. For each day of delayed flowering seed yield increased by $63 \mathrm{~kg} / \mathrm{ha}$ (Chase, 1964). Mundstock and Uitdewilligen (1971) and Silva (1972) obtained higher seed yield with earlymaturing hybrids than with late-maturing hybrids, but they did not mention anything about the fielddrying rate of the seeds. As a result, corn seed dry weight is difficult to evaluate, mainly due to the non-uniformity in the seeds of the ear and the ear variations among plants.

Hanway (1963) measured the dry weight of corn seeds, and described its accumulation through regressive equations as functions of time. The maximum values of these regressive equations were considered as the moment when dry weight accumulation ends in the seeds.

Rench and Shaw (1971) described the point of maximum physiological quality of corn seeds with moisture content and dry weight accumulation, and observed that those characteristics vary with genotype and seeding date. Several authors (Dessureaux, 1948; Shaw and Thom, 1951; Hallauer and Russel, 1961; Gunn and Christensen, 1965; Hillson and Penny, 1965; Andrew, 1965; Daynard and Duncan, 1969; Daynard, 1971) used 100 or more seeds from each ear to define the time of maximum seed dry weight. According to Daynard and Duncan (1969), the black layer method was considered most useful to evaluate maximum seed dry weight. The authors observed that the black layer could be formed in 3 to 4 days. Tekrony and Hunter (1995) observed maximum seed vigour around stage four of the black layer formation, and also stage four for milk line development, although maximum dry weight occurred at most at that stage. Vieira et al. (1995) suggested that the milk line development would be a useful method to be used in the field. To these authors, this method allows subdividing the reproductive period of corn into five parts (stages), and then verifying the moment of maximum seed quality. Fig. 1 shows a transition line between solid and liquid phases of corn seed endosperm in an ear cut in half, representing transitions between stages 3 and 4 of milk line development.

Experiments about corn seed harvesting have been conducted usually based on one or two of the previous mentioned seed characteristics. Although this research was conducted for one year, its objective was to enlarge this range to five simultaneous comparisons, in order to better identify seed quality.

The objective of this work was to evaluate the use of the milk line as an indicator of the physiological seed maturity and the time for harvesting seeds of three hybrids of corn (Zea mays L.) at their best physiological quality.

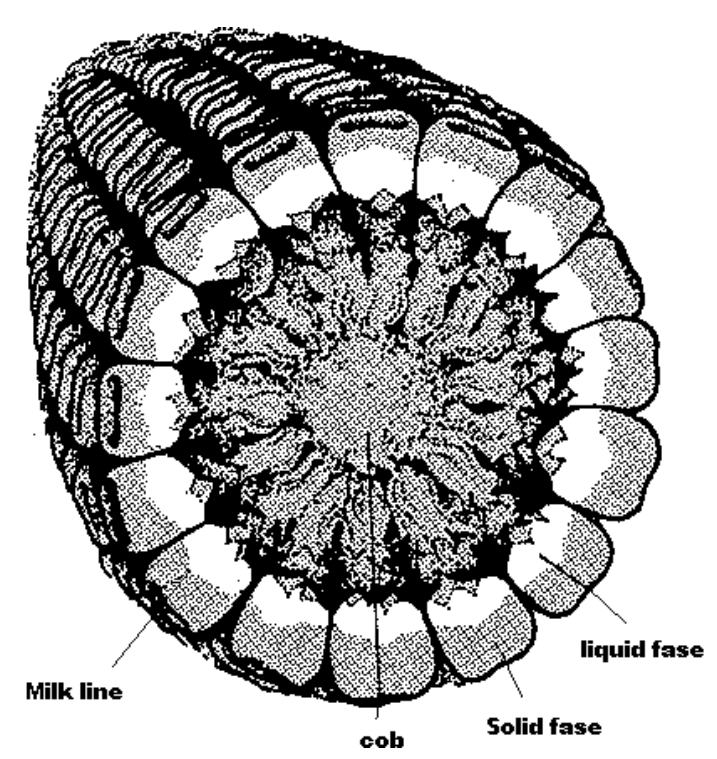

Figure 1 - Outline view of milk line in maize seeds on a cob cut in half (Havilah et al., 1995).

\section{MATERIALS AND METHODS}

The hybrids CD 1723 (single), OC 705 (double) and CD 5501 (single) developed by Coodetec were planted on September 30, 1996. When the ears started to appear, plants uniform in appearance were selected and tagged to be sampled later. The day $75 \%$ of the tagged plants in the plots showed 
$2.5 \mathrm{~cm}$ long silks, was considered the first day of female flowering.

A completely randomised block design with four replications was used. The corn hybrids were seeded in the plots and, in the subplots, 10 samples were consecutively taken in regular periods of four days (split-plot in time). The sampling was initiated 23 days after female flowering (DAFF) and the last sample was collected 59 DAFF. Each plot was composed by four twelve-meter lines, where the first and the last lines, as well as the meter-end portion of the second and third ones were considered as borderlines.

Thirty-four ears were sampled at each time. From each ear, 20 to 25 seeds were collected in the middle portion from a single row. After the ear was sampled for the first time, it was covered with a paper bag and tied with a rubber band, to prevent access to the ear through the opening where seeds were collected. This procedure was repeated after each ear sampling. Five seeds at random from each ear were taken to evaluate the black layer development and the milk line position.

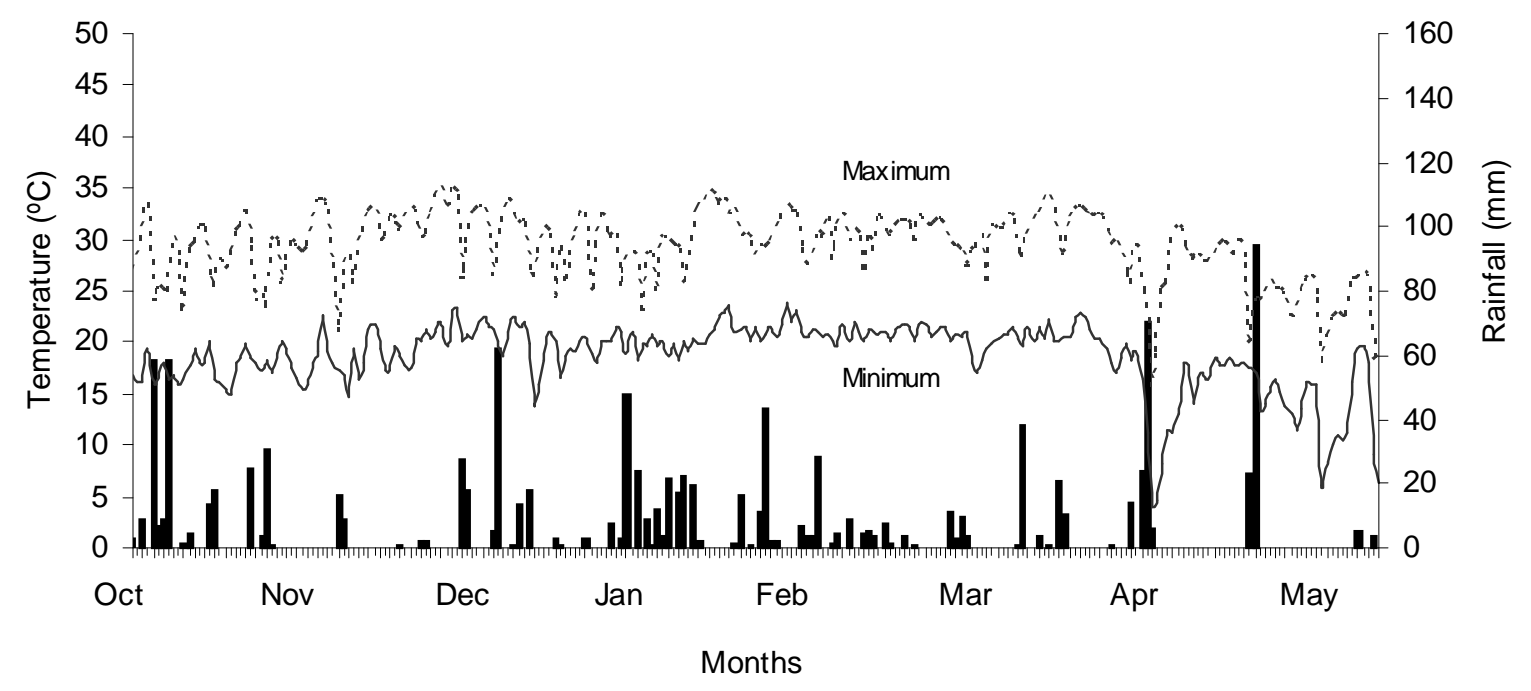

Figure 2 - Environmental conditions underwich the field tests were conducted.

The remaining seeds were put together as one sample and taken to the laboratory for evaluation of seed moisture content and seed germination percentage, according to the Brazilian Official Seed Analysis Rules (Brasil, 1992), dry seed weight and seed vigour using the cold and the accelerated aging tests. From time to time, with intervals of four days, seeds from the borderlines and at the same age as the ones being investigated were collected and their milk lines compared to verify the stage of development of the seeds remaining in each ear.

The environmental conditions under which the field tests were conducted are summarizes in Fig. 2. When the significant interaction between hybrids and sampling period were detected, the necessary unrolling was performed. The degree of adjustment of the equations was evaluated by the corrected coefficient of determination $\left(\mathrm{R}^{2}\right)$, by the
Student's $t$ test of significance of the regression coefficients, and by the $\mathrm{F}$ test of significance of the regression and its deviations $(\mathrm{P}<0.05)$. The analysed variables were seed dry weight, moisture content, germination percentage, cold and accelerated aging tests, milk line development and black layer appearance. Descriptive statistics was used for the last two variables. The germination percentage by using standard germination test and the moisture content of the seeds were analysed in the laboratory (Brasil, 1992). The cold and the accelerated aging tests followed the procedure described by Krzyzanowski et al. (1991). The milk line was evaluated according to Havilah et al. (1995), and the black layer appearance was based on the method proposed by Rench and Shaw (1971).

The statistical analysis was conducted using the software SAEG (Gomes and Braga Filho, 1992). 


\section{RESULTS}

Figs. 3, 5 and 7 show the seed dry weight accumulation of the three corn hybrids evaluated, which showed a quadratic relation to sampling moments for the three corn hybrids. The $\mathrm{R}^{2}$ for each equation was considered satisfactory. The adjusted equations for each hybrid and their $R^{2}$ were:

CD 1723: $\hat{Y}=-0.311+0.0241 * X-0.00024 * X^{2} \quad R^{2}=$ 0.99

OC 705: $\hat{Y}=-0.256+0.0205 * X-0.00019 * X^{2} \quad R^{2}=$ 0.99

CD 5501: $\hat{Y}=-0.219+0.0186 * X-0.00018 * X^{2} \quad R^{2}=$ 0.99

With the quadratic behaviour, the maximum values for each equation could be found. The hybrid CD 1723 completed the period from $75 \%$ female flowering to the maximum value of dry weight in 50.2 days. The hybrid CD 5501 completed this period in 51.7 days, with the lowest value of seed dry weight among the three hybrids. The hybrid OC 705 completed this period in 53.9 days, with seed dry weight intermediate to the two others. Those periods are related to stage 3 of black layer appearance and stage 4 of milk line development.
The moisture content variable showed a decreasing linear tendency for both hybrids CD 1723 and OC 705 (Fig 4 and 6). The hybrid CD 5501 (Fig 8) showed a quadratic decrease. The adjusted equations for those hybrids were:

CD 1723: $\hat{Y}=85.795-1.2130 * X \quad R^{2}=0.98$

OC 705: $\hat{Y}=83.397-1.1221 * X \quad R^{2}=0.99$

CD 5501: $\hat{Y}=117.350-3.0763 * X+0.02496 * X^{2} R^{2}=$ 0.98

This linear behaviour of hybrids CD 1723 and OC 705 meant that for each day of delay between collecting, the seed moisture decreased 1.21 and 1.12 points of moisture, respectively.

The period between female flowering and 30\% seed moisture content, the often used reference for harvesting in Brazil, was 44.3 days for CD 5501, 45.8 days for CD 1723 and 47.6 days for OC 705 . For each hybrid, the moisture content was reached before maximum dry weight and before the black layer turned visible. The milk line was around stage 4 at those maximum values.

The variable germination of seeds was adjusted in a cubic-model for CD 1723 (Fig 4), in a square root model for OC 705 (Fig 6) and in a quadratic model for CD 5501 (Fig 8). The $\mathrm{R}^{2}$ coefficient was considered statistically satisfactory, closely representing the observed data in the field.

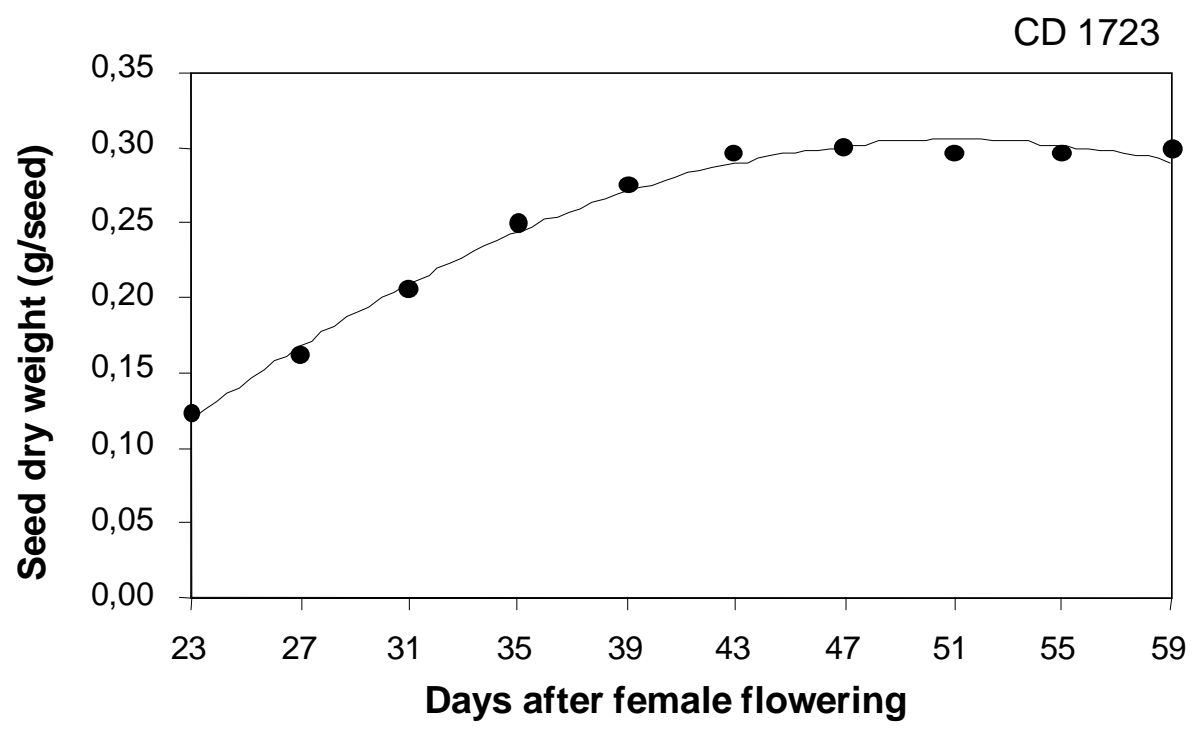

Figure 3 - Seed behaviour of variable accumulated dry weight of hybrid CD 1723 after female flowering. 


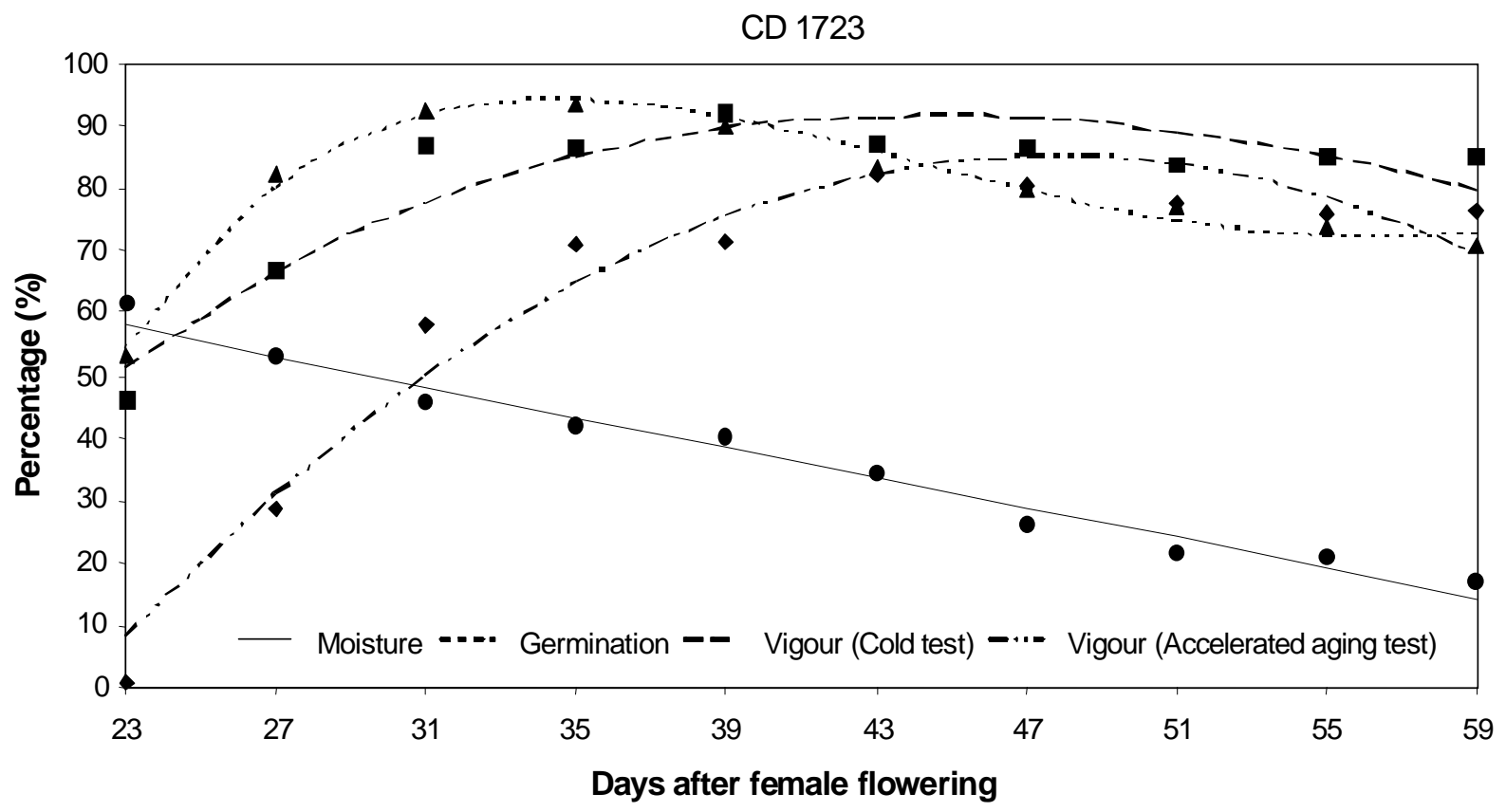

Figure 4 - Seed behaviour of variables germination, vigour by cold test and accelerated aging test and moisture content of hybrid CD 1723 after female flowering.

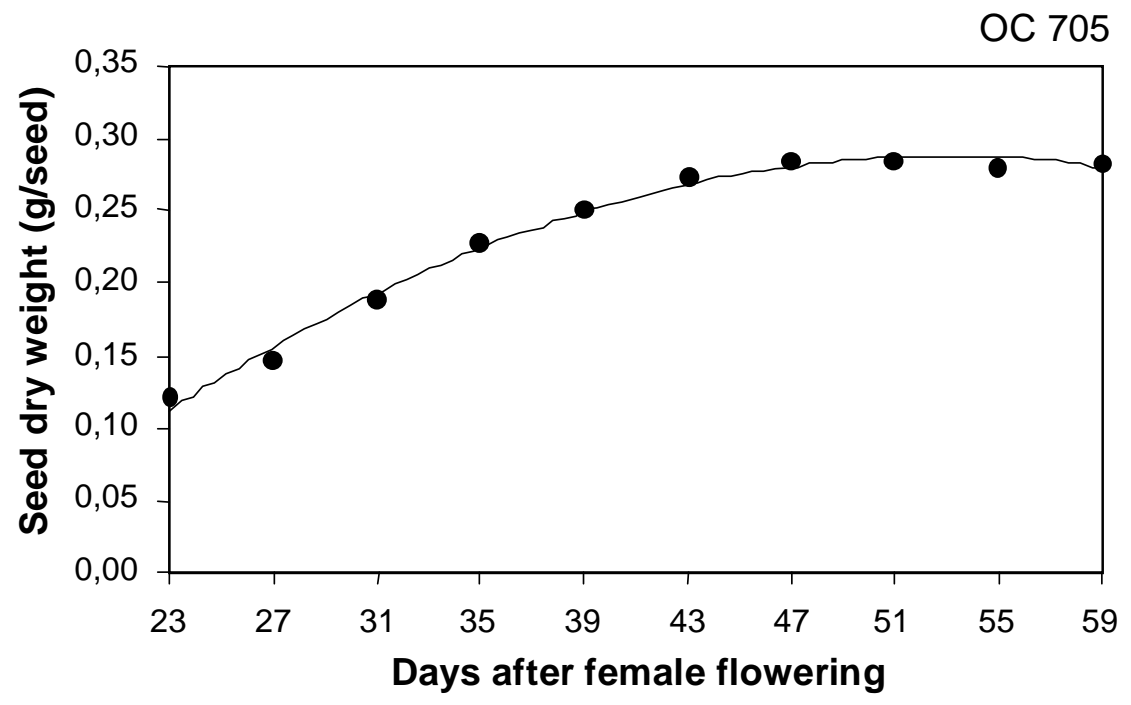

Figure 5 - Seed behaviour of variable accumulated dry weight of hybrid OC 705 after female flowering.

The adjusted equations to germination were:

CD 1723: $\hat{Y}=-2.731 .170+1.301 .8700 * X^{0.5}-$ $197.545 * X+9.83926 * X^{1.5} \quad R^{2}=0.98$
OC 705: $\hat{Y}=-497.717+177.4910 * X^{0.5}-13.30890 * X$ $\mathrm{R}^{2}=0.93$

CD 5501: $\hat{Y}=-110.784+8.1738 * X-0.07970 * X^{2} \quad R^{2}$ $=0.95$ 
The results showed that values over $80 \%$ for germination percentage started 26.4 DAFF for hybrid CD 1723, 34.1 DAFF for OC 705 and 35.9 DAFF for CD 5501. The highest percentage was estimated to occur 34.4 DAFF for CD 1723, at 44.5 DAFF for OC 705, and at 51.3 DAFF for CD
5501, all of them before the seed had reached the maximum dry weight. The black layer begun to show only for CD 1723. The milk line was evaluated as stage 2 for CD 1723, and as stage 4 for OC 705 and CD 5501.

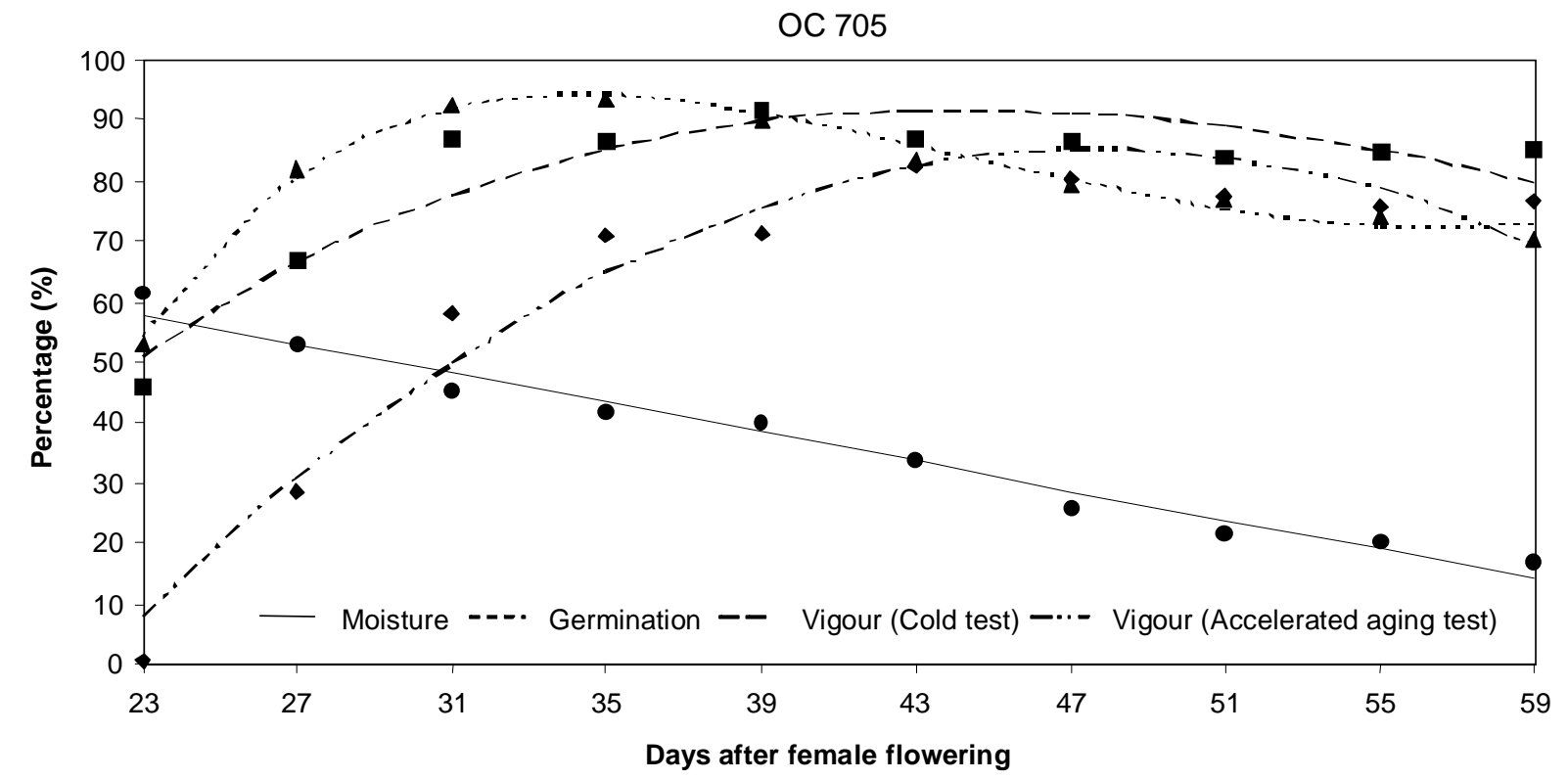

Figure 6 - Seed behaviour of variables germination, vigour by cold test and accelerated aging test and moisture content of hybrid OC 705 after female flowering.

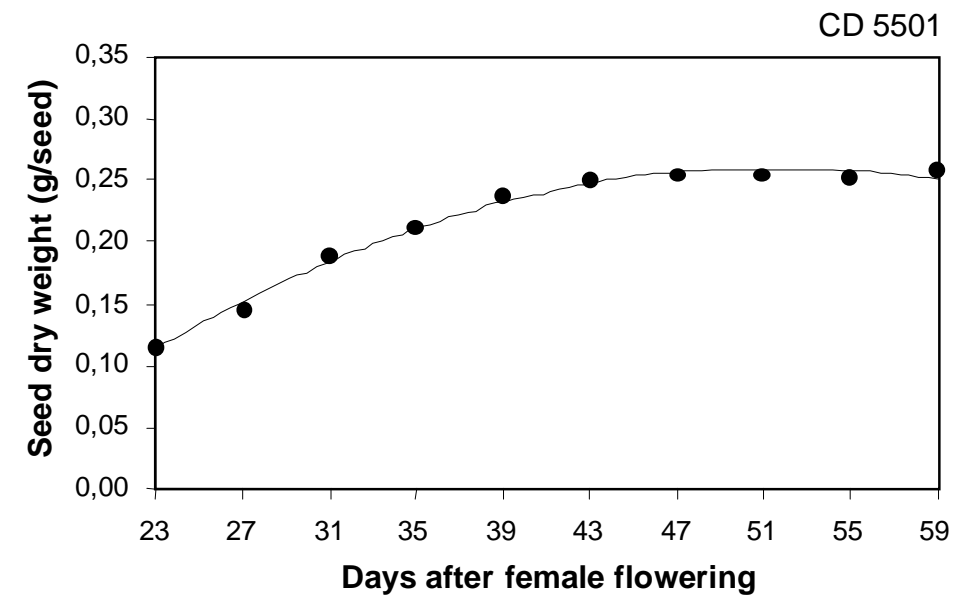

Figure 7 - Seed behaviour of variable accumulated dry weight of hybrid CD 5501 after female flowering. 
The seed vigour as indicated by the cold test is described by a square root model for CD 1723 and OC 705 (Fig 4 and 6), and by a quadratic model for hybrid CD 5501 (Fig 8).

The adjusted equations and their $\mathrm{R}^{2}$ coefficients were:

CD 1723: $\hat{Y}=-426.168+155.4340 * X^{0.5}-11.66550 * X$ $\mathrm{R}^{2}=0.87$

OC 705: $\hat{Y}=-423.655+148.5990 * X^{0.5}-10.8880 * X$ $\mathrm{R}^{2}=0.86$

CD 5501: $\hat{\mathrm{Y}}=-123.212+7.1082 * \mathrm{X}-0.05670 * \mathrm{X}^{2}$ $\mathrm{R}^{2}=0.97$

Values of maximum seed vigour were estimated from the equations above, and occurred at 44.4 DAFF for CD 1723, 46.6 DAFF for OC 705 and 62.7 DAFF for CD 5501. For the first two hybrids those times were before the seeds reached maximum dry weight. The black layer was becoming visible for CD 1723, but still not visible to the other two hybrids. The milk line was around stage 4 for CD 1723 and OC 705, and at stage 5 for CD 5501.

The seed vigour estimated by the accelerated aging test showed a quadratic tendency to sampling period for the hybrids tested in this work (Fig 4, 6 and 8). The adjusted $\mathrm{R}^{2}$ values were considered satisfactory. The adjusted equations to the hybrids in this test were:

CD 1723: $\hat{Y}=-202.985+12.0678 * X-0.12636 * X^{2}$ $\mathrm{R}^{2}=0.94$

OC 705: $\hat{Y}=-134.047+7.5461 * X-0.06617 * X^{2} \quad R^{2}$ $=0.94$

CD 5501: $\hat{\mathrm{Y}}=-160.803+8.9605^{*} \mathrm{X}-0.08126 * \mathrm{X}^{2}$ $\mathrm{R}^{2}=0.98$

The maximum values of vigour were found at 47.8 DAFF for CD 1723, 57.1 DAFF for OC 705, and 55.1 DAFF for CD 5501. Stages 3, 5 and 5 were attributed to those hybrids, respectively, for black layer, and 4,5 and 5 for milk line development.

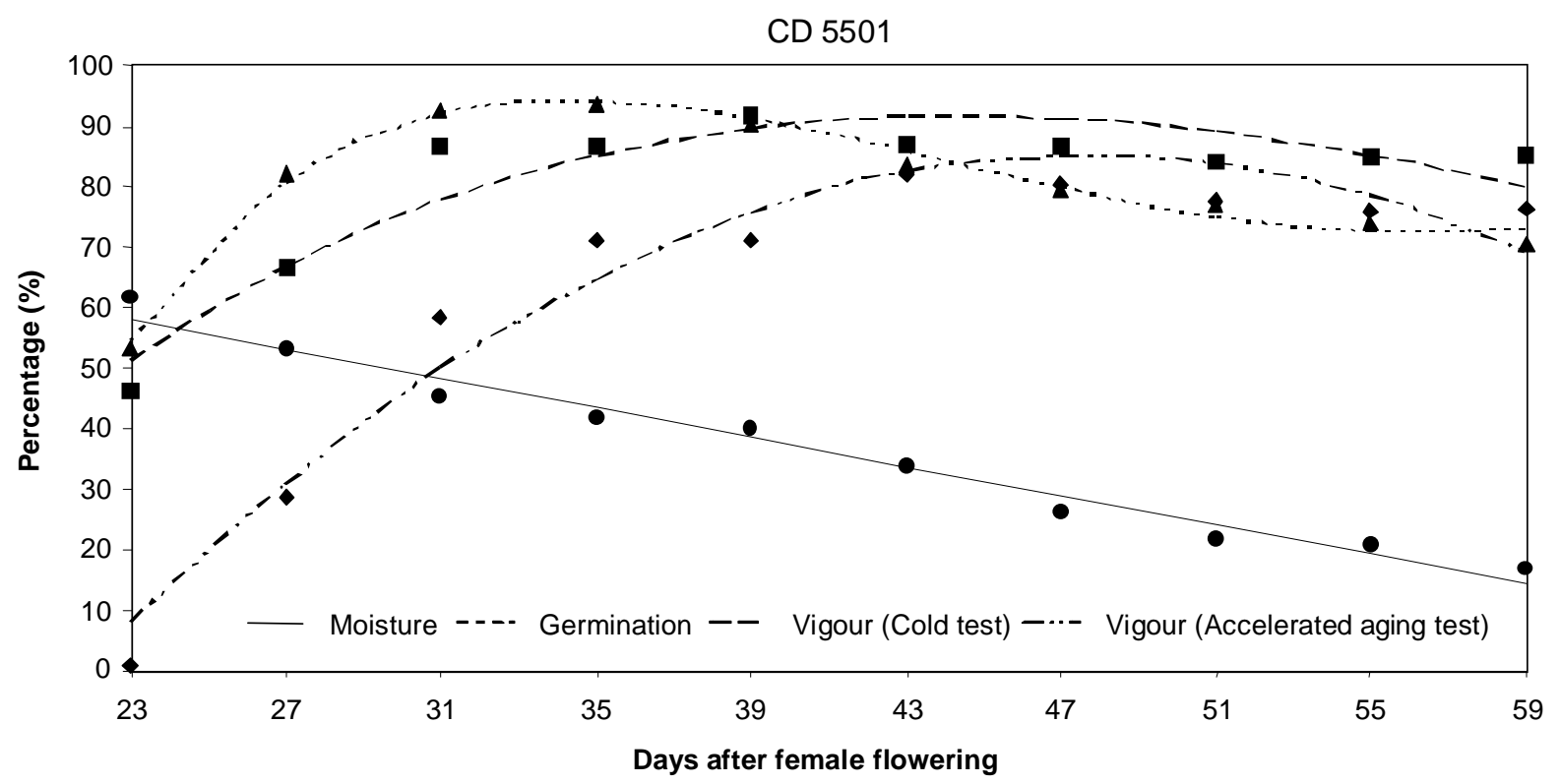

Figure 8 - Seed behaviour of variables germination, vigour by cold test and accelerated aging test and moisture content of hybrid CD 5501 after female flowering.

The beginning of seed abscission (stage 3) was observed in the light-brown placental-chalazal region $47 \mathrm{DAFF}$ for $\mathrm{CD} 1723$, and $51 \mathrm{DAFF}$ for OC 705 and CD 5501. For the apex and base seeds on the ear, the black layer development was less uniform than for seeds in central portion of the ear, and this non-uniform development of the black layer seems to be similar among the tested hybrids. Before the line of endosperm solidification became visible, some contents had turned to solid 
phase at the distal portion of the seed. After the milk line turned clearly visible, its development was easily observed. In addition, eight days were necessary for the milk line to change from one stage to another through progressive solidification of the milky content in the seed. This was observed in the three hybrids.

\section{DISCUSSION}

Seed dry weight is used to determine its maturity in the field. The three hybrids had similar quadratic mathematical models to describe their accumulated dry weight. Moisture content decrease in the seeds was estimated using two linear and a quadratic mathematical model one for each hybrid, all of them with high corrected coefficients of determination $\left(\mathrm{R}^{2}\right)$. Seed germination varied for the three hybrids. It increased until just after female flowering reached a maximum value, and then decreased. However, each of them had its own rate of changing: $C D$ 1723 increased its germination value rapidly, and decreased slowly after reaching the maximum point; the germination of OC 705 increased uniformly and decreased after reaching a maximum value similar to the previous hybrid; $C D$ 5501 took longer to reach the maximum value of germination, which was higher than the two other hybrids.

The results of cold and accelerated aging tests presented in this work indicated that around stage four of milk line was the maximum values of seed vigour. Also, those maximum values of vigour were closely related to the appearance of black layer (stage 3). The initial stages of black layer formation were difficult to determine, and required accurate observations when using the Rench and Shaw (1971) rating system. It was found that at 47 DAFF for CD 1723 and 55 DAFF for CD 5501 and OC 705, around $95 \%$ of the seeds showed the black layer fully developed, as found by Borba et al. (1994).

Maximum values of germination for CD 5501 and OC 705 were found before the black layer was visible, but the results of the other variables analysed in this work reached maximum values at the time when the black layer became visible (stage 3). However, it took only two to three days to change from stage 3 to stage 5 . The fast change from one stage to the other might be the main reason why more references were made to stage 5 of the black layer formation.

The stages of development of milk line were easy to follow during the process of endosperm solidification, because they only required the estimate of the percentage of the milky portion still remaining in the seed. The best harvesting time, as well as germination and vigour percentages, could be significantly related to those stages. The milk line was a better field indicator of the best harvesting time than black layer, because it allows harvesting according to known seed quality at the end of stage 3 and the beginning of stage 4 of the endosperm solidification. Also, the milk line allows referring to a specific stage of seed development, and is easier than black layer to be visualized (Hunter et al., 1995; Tekrony and Hunter, 1991).

Usually, the harvest of corn seeds is recommended when they are showing maximum values of vigour, germination and dry weight, and with low percentage of moisture. These optimum values do not coincide. However, all hybrids showed stage 4 of the milk line solidification as the closest time for maximum seed dry weight, as well as for desirable values of seed moisture content, germination, cold and accelerated aging tests.

\section{ACKNOWLEDGEMENTS}

We thank all support received from Coodetec, especially through Ivo Marcos Carraro and Celso Gonçalves de Aguiar.

\section{RESUMO}

O experimento foi conduzido durante $\mathrm{o}$ ano agrícola de 1996/97 em área experimental da Cooperativa de Desenvolvimento Econômico e Tecnológico (Coodetec), em Cascavel, Paraná, com o objetivo de avaliar o efeito da época de colheita de três híbridos de milho (Zea mays L.) na qualidade fisiológica das sementes e o uso da linha de solidificação do endosperma como indicativo da maturidade fisiológica das sementes. O plantio foi realizado em 30 de setembro de 1996. Amostras de sementes dos híbridos simples CD 1723 e CD 5501, bem como do híbrido duplo OC 705 , foram colhidas em intervalos de quatro dias, durante 59 dias, iniciando-se a colheita no 
vigésimo terceiro dia após o florescimento feminino. As características avaliadas nas sementes foram o acúmulo de matéria seca, o conteúdo de umidade, a germinação, o vigor (pelos testes de frio e de envelhecimento acelerado), a formação da camada preta e o desenvolvimento da linha de solidificação do endosperma. A colheita dos três híbridos realizada a partir dos 47 dias após o florescimento feminino identificada pela análise conjunta das sete características avaliadas, permitiu obter sementes com elevada qualidade fisiológica. O estádio 4 da linha de solidificação do endosperma demonstrou ser muito útil como indicador da época de colheita mais favorável a obtenção de sementes com elevada qualidade fisiológica, uma vez que diferentes estádios de desenvolvimento da linha de solidificação do endosperma em sementes de milho podem ser facilmente identificados no campo, na ausência de qualquer equipamento especial.

\section{REFERENCES}

Andrew, R. R. (1965), Maturation and yield of corn as influenced by climate and production technique. Agronomy Journal, 48, 231-236.

Borba, C. S.; Andrade, R. V.; Azevedo, J. T. and Oliveira, A. C. (1994), Maturidade fisiológica de sementes do híbrido simples BR-201 de milho (Zea mays L.). Revista Brasileira de Sementes, 16, 63-64.

Brasil. Ministério da Agricultura, do Meio-Ambiente e da Reforma Agrária. (1992), Regras para Análises de Sementes. Brasília : Departamento Nacional de Produção Vegetal.

Carter, M. W. and Poneleit, C. G. (1973), Black layer maturity and filling period variation among inbred lines of maize (Zea mays L.). Crop Science, 13, 436-439.

Chase, S. S. (1964), Relation of yield and number of days from planting to flowering in early maturity corn hybrids of equivalent grain early maturity maize hybrids of equivalent grain moisture at harvest. Crop Science, 4, 111-112.

Daynard, T. B. and Duncan, W. G. (1969), The black layer and grain maturity in corn. Crop Science, 9, 473-476.

Daynard, T. B. (1971), Duration of the grain-filling period and its relation to grain yield in maize (Zea mays L.). Crop Science, 11, 45-48.

Daynard, T. B. (1972), Relationships among black layer formation, grain moisture percentage, and heat unit accumulation in corn. Agronomy Journal, 64, 716-719.
Dessureaux, L. (1948), Maturation in corn. Journal of American Society of Agronomy, 40, 733-745.

Gomes, J. M and Braga, J. M. F. (1992), Sistema de análises Estatísticas e Genéticas (SAEG). Viçosa : Central de Processamento de Dados, Universidade Federal de Viçosa.

Gunn, R. B. and Christensen, R. (1965), Maturity relationships among early to late hybrids of maize (Zea mays L.). Crop Science, 4, 299-301.

Hallauer, A. R. and Russell, W. A. (1962), Estimates of maturity and its inheritance in maize. Crop Science, 2, 289-294.

Hallauer, A. R. and Russel, W. A. (1961), Effects of selected weather factors on grain moisture reduction from silking to physiologic maturity in corn. Agronomy Journal, 53, 225-229.

Hanway, J. J. (1963), Growth stages of corn (Zea mays L.). Agronomy Journal, 55, 487-492.

Hunter, J. L.; Tekrony, D. M.; Miles, D. F. and Egli, D. D. (1991), Corn seed maturity indicators and their relationship to uptake of carbon 14 assimilated. Crop Science, 31, 1309-1313.

Havilah, E. J.; Kaiser, A. G. and Nicol, H. (1995), Use a kernel milk line score to determine stage of maturity in maize crops harvested for silage. Autralian Journal of Experimental Agriculture, 35, 739-743.

Hillson, M. T. and Penny, L. H. (1965), Dry matter accumulation and moisture loss during maturation of corn grain. Agronomy Journal, 57, 150-153.

Kinitle, K. H. and Burris, J. S. (1976), Effect of kernel maturation on subsequent seedling vigor in maize. Crop Science, 16, 851-854.

Krzyzanowski, F. C.; França Neto, J. B. and Henning, A. A. (1991), Relato dos testes de vigor disponíveis para as grandes culturas. Informativo ABRATES, 1, 15-52.

Mundstock, C. M. and Uitdewlligen, W. P. M. (1971), Resultados experimentais de competição de cultivares de milho em três locais do Rio Grande do Sul. Porto Alegre : Faculdade de Agronomia, Universidade Federal do Rio Grande do Sul.

Rench, W. and Shaw, R. H. (1971), Black layer development in corn. Agronomy Journal, 63, 303-309.

Shaw, R. H. and Thom, H. C. S. (1951), On phenology of field corn: silking to maturity. Agronomy Journal, 43, 541-546.

Silva, P. R. F. (1976), Determinação dos efeitos de quatro densidades no rendimento de grãos $e$ características agronômicas, em seis cultivares de milho. MSc Thesis, Universidade Federal do Rio Grande do Sul, Porto Alegre, Brasil.

Tekrony, D. M. and Hunter, J. L. (1995), Effect of seed maturation and genotype on seed vigour in maize. Crop Science, 35, 857-862. 
Vieira, R. D.; Minohara, L.; Carvalho, N. M. and Bergamaschi, M. C. M. (1995), Relationship of black layer and milk line development on maize seed maturity. Scientia Agricola, 52, 142-147.

Williams, W. A. (1965), Vegetative growth of corn as affected by population density. II. Components of growth, net assimilation rate and leaf-area index. Crop Science, 5, 215-219.

Received: March 14, 2003;

Revised: March 29, 2004; Accepted: September 17, 2004. 